

\section{World Review of Nutrition and Dietetics}

\section{Vol. 86}

Series Editors

Advisory Board
Artemis P. Simopoulos

The Center for Genetics, Nutrition and Health, Washington, D.C., USA

Åke Bruce, Sweden

Ji Di Chen, China

Jean-Claude Dillon, France

J.E. Dutra de Oliveira, Brazil

Claudio Galli, Italy

Ghafoorunissa, India

Uri Goldbourt, Israel

C. Gopalan, India

Tomohito Hamazaki, Japan

Demetre Labadarios, South Africa

Paul J. Nestel, Australia

Konstantinos N. Pavlou, Greece

A. Rérat, France

Victor A. Rogozkin, Russia

Ricardo Uauy-Dagach, Chile

Antonio Velazquez, Mexico

Paul Walter, Switzerland 


\title{
Street Foods
}

\author{
Volume Editors A.P. Simopoulos \\ The Center for Genetics, Nutrition and Health, \\ Washington, D.C. \\ R. V. Bhat \\ National Institute of Nutrition, \\ Indian Council of Medical Research, India
}

8 figures and 21 tables, 2000

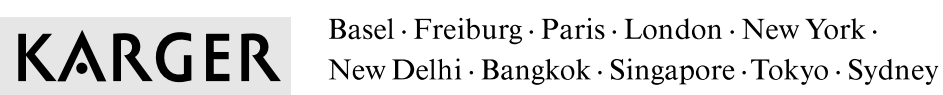




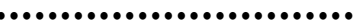

Artemis P. Simopoulos

4330 Klingle Street, N.W.

Washington, DC 20016 (USA)

\section{Ramesh V. Bhat}

National Institute of Nutrition

Indian Council of Medical Research

Hyderabad (India)

Library of Congress Cataloging-in-Publication Data

Street foods / volume editors, A.P. Simopoulos, R.V. Bhat

p. cm.- (World review of nutrition and dietetics; vol. 86)

Includes bibliographical references (p.).

ISBN 3-8055-6927-0 (hardcover)

1. Cookery, International. 2. Snack foods. 3. Vending stands. I. Simopoulos, Artemis

P., 1933- II. Series.

QP141.A1 W59 vol. 86

[TX725.A1]

641.59-dc 21

99-026676

Bibliographic Indices. This publication is listed in bibliographic services, including Current Contents ${ }^{\circledR}$ and Index Medicus/Medline.

Drug Dosage. The authors and the publisher have exerted every effort to ensure that drug selection and dosage set forth in this text are in accord with current recommendations and practice at the time of publication. However, in view of ongoing research, changes in government regulations, and the constant flow of information relating to drug therapy and drug reactions, the reader is urged to check the package insert for each drug for any change in indications and dosage and for added warnings and precautions. This is particularly important when the recommended agent is a new and/or infrequently employed drug.

All rights reserved. No part of this publication may be translated into other languages, reproduced or utilized in any form or by any means electronic or mechanical, including photocopying, recording, microcopying, or by any information storage and retrieval system, without permission in writing from the publisher.

(C) Copyright 2000 by S. Karger AG, P.O. Box, CH-4009 Basel (Switzerland)

www.karger.com

Printed in Switzerland on acid-free paper by Reinhardt Druck, Basel

ISSN 0084-2230

ISBN 3-8055-6927-0 


\section{Contents}

VII Preface

1 Greek Street Food Vending: An Old Habit Turned New Matalas, A.-L.; Yannakoulia, M. (Athens)

25 Street Foods in America - A True Melting Pot

Taylor, D.S.; Fishell, V.K.; Derstine, J.L.; Hargrove, R.L.; Patterson, N.R.; Moriarty, K.W.; Battista, B.A.; Ratcliffe, H.E.; Binkoski, A.E.;

Kris-Etherton, P.M. (University Park, Pa.)

45 Public (Street) Foods in Australia

Wahlqvist, M. (Victoria); Worsley, A. (Adelaide); Flight, I. (Victoria)

53 Profile of Street Foods Sold in Asian Countries Bhat, R.V.; Waghray, K. (Hyderabad)

100 Street Foods in Africa

Bhat, R.V.; Waghray, K. (Hyderabad)

123 Street Foods in Latin America Bhat, R.V.; Waghray, K. (Hyderabad)

138 Sale of Street Food in Latin America The Mexican Case: Joy or Jeopardy?

Muñoz de Chávez, M.; Chávez Villasana, A.; Chávez Muñoz, M.; Eichin Vuskovic, I. (Xochimilco)

155 Street Food Vending: The Israeli Scenario Gvion-Rosenberg, L. (Tel-Aviv); Trostler, N. (Rehovot)

169 Author Index

170 Subject Index 


\section{............................. \\ Preface}

This volume on Street Foods provides an overview of their status in selected developed and developing countries.

The Food and Agricultural Organization of the United Nations (FAO) defines street foods as 'ready-to-eat foods and beverages prepared and/or sold by vendors and hawkers, especially in streets and other similar public places'. Street foods are a heterogeneous food category consisting of meals, drinks and snacks. They are inexpensive and available foods that, in many countries form an integral part of the diet, because they are consumed with regularity and consistency across all income groups, but particularly among the urban poor and in some countries, by children.

International organizations have paid particular attention to the safety of street foods and much less to the composition and preservation of their nutritional quality. In 1996, the World Health Organization's (WHO) Food Safety Unit Report on the essential safety requirements for street-vended foods stated that proper preparation and processing techniques are essential for ensuring the safety of street-vended foods. Three critical roles of preparation and processing were identified in the report:

(1) Preparation and processing should be adequate to eliminate or reduce hazards to an acceptable level.

(2) Preparation and processing should prevent growth of pathogens, production of toxic chemicals and the introduction of physical hazards.

(3) Preparation and processing should ensure that foods are not recontaminated.

Preparation and processing will also affect the nutritional quality of food via their influences on nutrient loss. Although fat-soluble vitamins and minerals are generally fairly stable, water-soluble vitamins are easily lost in preparation, processing, and storage. Vitamin C, thiamin, and folate are especially susceptible to being lost or destroyed. 
The street food trade is large and complex. It provides an important means of generating income, particularly for women, and it is an affordable source of food for many millions of people. Therefore, street foods have been considered as a way of reducing problems of urban food insecurity and as a possible vehicle for micronutrient supplementation.

Although most of the reports have focussed mainly on developing countries, the street food trade is found in developed countries as well. Over the past 25 years, changing lifestyles have led to large numbers of people eating out. Many office workers in cities are apt to get their lunch from street vendors and many tourists in both developed and developing countries are eager to sample local fare. It is therefore timely to review the status of street foods not only from the food safety aspects, but also to examine consumption patterns and nutritional quality in selected developed and developing countries.

The authors present information on the historical aspects, profiles of street vendors and consumers, safety and nutritional quality, types of foods, snacks and drinks, and licensing.

The first paper is 'Greek street food vending: An old habit turned new' by Antonia-Leda Matalas and Mary Yannakoulia. In Greece, street foods made their appearance in the 6th Century BC with the development of urban communities. Hot lentil soup was the only available street food in the 'agora' of the Greek cities, but eating while wandering around the market was not considered appropriate. Many foods popular in ancient times were rediscovered during the Byzantine period and are popular today. The authors provide a precise evolution of the main Greek street foods from the ancient times to the present. Price is a minor factor in the selection of street foods; taste, quality and freshness are the food attributes Greeks are looking for in selecting street foods. Street foods enjoy a wide accessibility because most of the foods are not hazardous to health. The authors describe the licensing, processing, packaging and distribution of street foods. They consider street foods under these categories: (a) foods without any preparation; (b) street cooked foods, and (c) ready-to-eat foods. They provide extensive information on the nutritional, chemical and microbiological quality of street foods. The business of street foods is dominated by men. The authors conclude that street foods will hold a bigger share of the market in the future.

The next paper 'Street foods in America: a true melting pot' is by Denise Taylor and co-workers. In the USA, there is a vast array of food choices, but relatively little information about consumption patterns and their contribution to the diet of Americans. This paper provides an overview of the foods available and the health, safety and regulatory issues associated with consumption of street foods. Street foods have been part of the American scene since the 17th century. The street vendor market became a business that the lower class 
maintained, both as vendors and consumers. In describing the historical aspects of street foods, the authors indicate that many of the restaurant chains began as single street food stands. The types of food sold represent the ethnic groups that make up the US population today. Four cultures stand out: Italian, Mexican, Middle Eastern, and Chinese. However, many other street foods include Navajo fry bread, German bratwurst, Greek gyro and souvlaki, Indian samosas, Japanese yakitori, Caribbean roti and patties, and Argentine empanadas. The authors provide information of the nutritional quality of the street foods and discuss the microbial quality of street foods, the problems of food poisoning, the regulatory issues surrounding street foods and the profile of street vendors. Women play a minor role in street vending in the USA whereas they play a prominent role in developing countries.

The third paper 'Public (street) foods in Australia' is by Mark Wahlqvist and co-workers. They state that the concept of street foods is rarely seen as being a part of developed countries such as Australia with its 5,400 supermarkets and 130,000 other retail establishments. The preferred term is 'public foods' rather than 'street foods' since the locations of supply and consumption are more varied than the street, e.g. sports grounds, church fetes, shopping malls, cinemas. By 'public foods' they refer to the immediate purchase and consumption of ready-to-eat foods in public places. Public foods have an element of environmental proximity about them which require little anticipation, planning or preparation on the part of the consumer. They form part of the class of convenience foods but are purchased and usually consumed in a public location - though some foods are undoubtedly purchased for later consumption in the home, e.g. jams, preserved fruit and cakes from church and other fetes. They are part of a rising trend in Australian and other western societies, the convenience food trend.

The next paper 'Profile of street foods sold in Asian countries' is by Ramesh V. Bhat and Kavita Waghray. Although street foods have been around for hundreds of years, the proliferation of street foods in Asian countries is a new phenomenon. It began in the 1940s. Foods are selected because of taste and low cost, they are not selected for their nutritional value, although the food energy and protein value of cooked street food is higher than that which could be obtained from prepackaged processed food. The authors consider food safety a major issue and for this reason describe in detail the Hazard Analysis Critical Control Points (HACCP) on how to conduct the HACCP analysis in the field to determine critical control points. The HACCP concept has been applied to street foods in $23 \%$ of the countries which participated in the WHO street-vended food survey.

Drs. Bhat and Waghray continue with their paper 'Street foods in Africa'. Studies conducted in some of the African countries like Nigeria and Morocco 
have shown that the major street food vendors usually earn more than the country's minimum wage. In Nigeria it is cheaper to buy street food than to cook it. Eating street foods begins in infancy. In Senegal, yogurt is frequently given to the babies as weaning food and is never prepared at home. Street foods were the major source of nutrients for many of the adolescents $(n=142)$ in Abeokuta (Nigeria). Between 40 and 70\% intake of all the major sources of food groups were obtained from street foods which were the major source of dairy products $(70 \%)$, legumes $(60 \%)$, fish $(50 \%)$, meat $(50 \%)$ and eggs (50\%); $21 \%$ of energy for males and $29 \%$ energy for females was supplied by street foods. Street foods also supplied greater than $50 \%$ total proteins, $64 \%$ calcium and $60 \%$ vitamin A for both males and females. For other minerals (iron) and vitamins (thiamine and ascorbic acid) street foods supplied greater than $50 \%$ of total intake. Selection of street foods is based on taste, price, and last on nutritional quality.

Drs. Bhat and Waghray also examine 'Street foods in Latin America' in the next paper. Street food industry is part of the informal economy of the Latin American countries. Most of the street vendors earn more than the minimum wage.

Miriam de Chavez and co-workers look specifically at Mexican street food in 'The sale of street food in Latin America. The Mexican case: Joy or jeopardy?' in the paper which follows. Mexico has an old tradition of street foods. Fruits and juices are prominent items along with cooked snacks and meals. As in other Latin American countries, food safety and licensing are important issues, as are the economic aspects of street foods which represent an important sector of the economy.

Liora Gvion-Rosenberg and Naomi Trostler describe 'Street food vending: The Israeli scenario' in the final paper. Street food vending as seen in developing countries is not part of the Israeli gastronomic scene. The Israeli version of street foods is generally available at kiosks and small shops. Falafel, sunflower seeds, nuts, ice cream or pizza are all part of the daily culinary street scene. Israeli food fairs are also described. The nature of the Israeli trend in street foods includes two major characteristics. First, it is an established and organized activity, mainly localized in commercial urban centers. Second, it is mainly for snacking purposes, and does not conform to the FAO definition because it is neither prepared nor sold by street vendors and hawkers.

This volume should be of interest to scientists and policy makers in the area of international health, nutrition, food and trade; and to physicians, nutritionists, dieticians, food scientists, anthropologists, sociologists and directors of public health departments.

Artemis P. Simopoulos, MD 